\title{
FLOW STRUCTURE OF COARSE-GRAINED SLURRY IN A HORIZONTAL PIPE
}

\author{
PAVEL VLASAK*), BOHUS KYSELA, ZDENEK CHARA \\ Institute of Hydrodynamics of Academy of Sciences of the Czech Republic, v. v. i., Pod Patankou 30/5, \\ 16612 Prague 6, Czech Republic; *)Mailto: vlasak@ih.cas.cz, phone: +420 233109019, fax: +420 233324361
}

The flow behaviour of coarse-grained slurry depends on particle size, shape, density and concentration, and on the density and rheological properties of the carrier liquid. The present paper describes the results of an experimental investigation and flow visualisation of model coarse-grained particle-water mixtures in a closed pipe loop with smooth stainless steel pipes of inner diameter $36 \mathrm{~mm}$. Glass balls and washed graded pebble gravel of mean diameter $d_{50}=6 \mathrm{~mm}$ were used as model coarse-grained material. The effect of slurry velocity and particle concentration on the slurry flow behaviour and pressure drop in the turbulent regime was evaluated. Particle distribution in the pipe cross-section and motion of particles along the pipe invert, particle saltation and particle conveying in the carrier liquid were investigated in a transparent pipe viewing section and motion of individual particles was described. Velocity profiles of the carrier liquid and conveyed particles were determined.

KEY WORDS: Coarse-Grained Slurry, Turbulent Flow, Pressure Drop, Velocity Distribution, Flow Structure, Concentration Effect.

Pavel Vlasák, Bohuš Kysela, Zdeněk Chára: STRUKTURA PROUDU HRUBOZRNNÉ SUSPENZE V HORIZONTÁLNÍM POTRUBÍ. J. Hydrol. Hydromech., 60, 2012, 2; 30 lit., 12 obr.

Tokové chování hrubozrnných suspenzí závisí na velikosti, tvaru a hustotě částic, koncentraci pevné fáze a hustotě a reologických vlastnostech nosné kapaliny. Článek popisuje výsledky experimentálního výzkumu a vizualizace proudění modelové hrubozrnné suspenze v experimentální potrubní lince s hladkým nerezovým potrubím s vnitřním průměrem $36 \mathrm{~mm}$. Skleněné kuličky a praný oblý štěrk (kačírek) se středním zrnem $d_{50}=6 \mathrm{~mm}$ byly použity jako modelový materiál. Byl vyhodnocen vliv rychlosti proudění suspenze a koncentrace pevné fáze na chování a tlakové ztráty suspenze. Rozdělení částic $\mathrm{v}$ příčném prưřezu potrubí a pohyb částic podél dna potrubí, jejich saltace a unášení v nosné kapalině byly zkoumány $\mathrm{v}$ transparentní části potrubí a byl popsán pohyb jednotlivých částic a pro vybrané př́ipady byly stanoveny rychlostní profily nosné kapaliny a unášených částic.

KLÍČOVÁ SLOVA: hrubozrnné suspenze, turbulentní proudění, tlakové ztráty, rozdělení rychlostí, struktura proudu, vliv koncentrace.

\section{Introduction}

Pipeline transport of coarse-grained material is not very frequently used due to the problem of severe wear, material degradation, high critical velocity and consequently also operational velocities and energy requirement. However, pipeline transport of coarse particles (with diameter greater than $50 \mathrm{~mm}$ ) is of potential importance in the Alberta oil sands industry, Shook et al. (2002). Both sand slurries and non-Newtonian clay slurries are possible transport media. Similarly, the most suitable method for transport of poly-metallic nodules (which contain a number of metals and therefore their exploitation will be probably occurring in the near future) from the ocean bottom to the surface is hydraulic pipelining (Maciejewski et al., 1993; Vlasak et al., 2011).

The pressure drop of coarse-grained slurries depends on the flow velocity, solids concentration, density, shape, and size distribution of the conveyed solid material, the size and roughness of the pipe, and also the mutual particle-particle, particleliquid and particle-wall interactions. For heterogeneous and coarse-grained slurries the deposition velocity is a very important parameter; at least as importance as friction losses for design and operation (Matousek, 2009; Vlasak and Chara, 2004). The internal friction in the conveyed slurry and the friction between the conveyed material and the pipe 
produce a pressure drop, which determines the energy and pump technology requirements.

The understanding of the slurry flow behaviour makes it possible to optimize energy requirements, to improve quality, safety, economy and reliability of transport and/or processing of the transported material. Advanced knowledge of the flow behaviour coarse-grained and complex slurries is therefore important for the safe, reliable and economical design and operation of pipeline technology. The preferred predictive tools are models based on the physical description of slurry flow behaviour in a pipeline (Matousek, 2005).

With the construction of large industrial pipelines in the 1950's, demand for reliable models capable of predicting slurry flow behaviour grew. Many empirical correlations exist for heterogeneous slurries which can be used successfully after calibration (Govier and Aziz, 1972; Kupka et al., 1970). The first substantial contribution to understanding of coarse-grained slurry flow was made by Durand (1951) and Durand and Condolios (1952). For mono-disperse particles conveyed by liquid in horizontal pipe Durand (1951) proposed an empirical relationship for the dimensionless Durand function

$$
\begin{aligned}
& \phi=\left(i_{S}-i_{o}\right) / i_{o} \cdot c_{v}= \\
& =K\left[\operatorname{Fr} / \sqrt{\operatorname{Fr}_{w}\left(\rho_{p} / \rho_{o}-1\right)}\right]^{-\alpha},
\end{aligned}
$$

where $i_{o}$ and $i_{s}$ - the carrier liquid and slurry hydraulic gradient, respectively, $c_{v}$ - the slurry volumetric concentration, $K$ - material constant, $\mathrm{Fr}=$ $=V_{s}^{2} / \mathrm{g} D$ and $\mathrm{Fr}_{w}=w_{50}^{2} / \mathrm{g} D-$ the slurry and mean particle Froude numbers, $\rho_{o}$ and $\rho_{p}$ - the water and particle density, respectively, $d$ - the particle mean diameter, $D$ - the pipe diameter, $V_{s}$ - slurry mean velocity, $w_{50}-$ the fall velocity of a medium sized particle.

The right hand side of Eq. (1) can be simplified to

$$
\begin{aligned}
& K\left[\operatorname{Fr} / \sqrt{\operatorname{Fr}_{w}\left(\rho_{p} / \rho_{o}-1\right)}\right]^{-\alpha}= \\
& \left.=K\left[\operatorname{Fr}_{w}\left(\rho_{p} / \rho-1\right)\right]\right]^{\alpha / 2} \cdot \operatorname{Fr}^{-\alpha}=\beta \cdot \mathrm{Fr}^{-\alpha},
\end{aligned}
$$

where $\beta$ and $\alpha$-slurry material parameters, which can be determined from experimental data. The relationship of the Durand function $\varphi$ versus slurry Froude number Fr
$\phi=\left(i_{S}-i_{o}\right) / i_{o} \cdot c_{v}=\beta \cdot \mathrm{Fr}^{-\alpha}$

could be represented by a linear dependence in a log-log plot (Vlasak and Chara, 2011). The Durand model provides a simple tool for a wide range of slurry conditions, it can be used to scale up the frictional pressure drops of the heterogeneous slurry, when the material parameters are determined experimentally (Vlasak and Chara, 2007).

Disadvantage of the Durand model is a low accuracy for the lower and higher velocity range, especially for fully-stratified and fully suspended flow pattern. Silin and Kobernik (1962) found that the model could be used within the range $4<\mathrm{Fr} / \mathrm{Fr}_{w}{ }^{1 / 2}$ $<15$. Zandi and Govatos (1967) declared that the Durand model is invalid if the saltation mode of solids transport occurs and that the constant $K$ for ratios of $\mathrm{Fr} / \mathrm{Fr}_{w}{ }^{1 / 2}<10$ is different to those valid for $\mathrm{Fr} / \mathrm{Fr}_{w}{ }^{1 / 2}>10$.

For this reason attempts have been made to find a general model of slurry flow. The first mechanistic equation for coarse-grained particle flow was probably that of Newitt et al. (1955), who distinguished between fluid friction, which is velocity dependent, and particle-wall friction of the Coulomb type, which is independent of velocity. Both types of friction occur when coarse particles are transported. Newitt et al. (1955) defined coarse particle conveying as special pipeline flow, which can be described as flow with sliding bed and particle saltation.

A slurry flow mechanism can be theoretically described by a set of differential equations for the conservation of mass, momentum and energy in the slurry flow pattern. So called a microscopic model provides a numerical solution to the equations in the local position of a cross-section and as a result it predicts the concentration and velocity profiles in the pipe cross-section together with the pressure drop over a pipeline length section (Shook and Roco, 1991). The microscopic models employed a very large number of empirical coefficients, which have to be determined from experimental measurements. Unfortunately, the experimental technique is not able to provide enough information on the slurry flow mechanism at a microscopic level and the model remains only theoretical.

A compromise between the microscopic and empirical approaches is macroscopic modelling, which applies the conservation equations to a large control volume of slurry. It could be a pipe cross-sectional area with approximately uniform concentration of 
solids in a unit length of a pipe. In the chosen volume the conservation equations are formulated using averaged quantities over the control volume.

The mechanistic approach for coarse particles was first made rigorous by Wilson who interpreted the very high concentration experimental results of Streat and Bantin (1972). They used idealized conditions (mono-sized glass spheres and smooth pipes) which defined the friction process clearly.

To extend this model to lower concentration, Wilson (1976) proposed for settling slurries a twolayer model, with clear fluid in the upper layer. Wilson and Thomas (1985) considered a fully stratified flow in which all particles are concentrated in the lower portion of the pipe (concentration in the layer near the pipe invert approaches the loosepacked value) and the Coulombic contribution to particle-wall friction is dominant. In the upper layer only clear fluid is presented. Only two coefficients are required to predict the pressured drop and the relationship between in-situ and transport concentrations. These coefficients are coefficient of Coulombic sliding friction between solid particles and pipe wall, and the friction at the interface between the two layers, which could be treated as a rough boundary. For the slurry flow Coulombic friction may be slightly velocity-dependent.

The two-layer model was extended even for finer particles based on experimental data from the large test pipelines of the Saskatchewan Research Council (Shook et al., 1986, Gillies et al., 1991). The RSC two-layer model (Shook and Roco, 1991; Shook et al., 2002) is based upon force balance for the upper and lower horizontal layers:

Upper layer:

$-d P / d z=\left(\tau_{1} S_{1}+\tau_{12} S_{12}\right) / A_{1}$,

lower layer:

$-d P / d z=\left(\tau_{2} S_{2}-\tau_{12} S_{12}+F_{2}\right) / A_{2}$,

where $\tau_{1}, \tau_{2}$ - kinematical stresses, respectively, $S_{l}$. $S_{2}$ - partial perimeters and $A_{1}, A_{2}$ - cross-sectional area of the upper and lower layer, respectively, $F_{2}-$ Coulombic force and $\tau_{12}$ - interfacial friction factor. The model satisfied the material balance constraints on total flow and solids transport rate for $V_{i}$ as bulk velocity in the respective layer or total in situ solids concentration $c_{i}$ is related to the partial concentrations by

$A V=A_{1} V_{1}+A_{2} V_{2}$

and $c_{v} A V=c_{1} A_{1} V_{1}+c_{2} A_{2} V_{2}$ or $c_{v} A=c_{1} A_{1}+c_{2} A_{2}$.

The two layer model recognizes the difference between the velocities of the particles and the fluid (Maciejewski et al., 1993). In the present version of the so-called RSC model slip is neglected within each layer. However, because the layers differ in solids concentration and velocity, there is a difference in the mean velocities of the particles and the fluid for the pipe as a whole.

Since the layers represent an oversimplification which is useful for rational analysis, the friction factor must be regarded as a correlating parameter whose magnitude cannot be entirely interpreted physically. Slip between the particles and the fluid results in a continuous transfer of energy from the fluid to the particle and this in turn requires energy to be transferred from the particle to the wall. The trajectory of a single particle has been described by many research workers, as a skipping motion (saltation) which produces intermittent contact with the wall. The time-average retarding force on a particle was assumed by Newitt at al. (1955) to be proportional to the immersed weight of the particle.

All the above mentioned quantities, including the Reynolds number, friction factor and Coulombic friction are defined for each layer as well as the interfacial friction factor $f_{12}$ and the flow parameters could be determined (Matousek and Krupicka, 2009). The two-layer model may be used for the description of the fully or partially stratified flow patterns and prediction of the deposition velocity limit, pressure drop due to friction, thickness and translational velocity of the sliding-bed, and also the value of the mean slip between the solid and liquid phases (Matousek, 1997). It can be used for high values of concentration (Gillies and Shook, 2000) and also in the case of the non-Newtonian carrier (Pullum et al., 2004). The presence of the stationary layer introduces an additional independent variable - the thickness of the bed deposit layer.

\section{Experimental equipment and material}

The present paper describes experimental investigation of two different coarse-grained particle conveyed by water. The mixture flow parameters were measured on an experimental closed pipe loop with a test section of smooth stainless steel pipes with an inner diameter $D=36 \mathrm{~mm}$, see Fig. 1 (Vlasak and Chara, 2011). The mixture was forced 
by a booster pump, WARMAN 3/2 C - AH, from an open storage tank, a variable speed drive was used to control slurry flow rates.

The mixture flow-rate and concentration were measured by a KROHNE-CORIMASS- 800 G+ mass flow-meter. The maximum mean mixture velocity $V_{s}$ was about $6 \mathrm{~m} \mathrm{~s}^{-1}$. The measurement section was equipped with three Hottinger-Baldvin PD-1 differential pressure transducers (measuring range up to $0.1 \mathrm{MPa}$, carrier frequency $5 \mathrm{kHz}$ ) monitored by a computer. The accuracy of the transducers was declared as $1 \%$ of the individual subranges, the accuracy of the mass flow-meter about
$2.5 \%$. With respect to the accuracy of the pressure transducers and flow rate measurement, the possible measurement error in the pressure gradient value is less than $3 \%$.

A two meter long, transparent section was used for visual observation of flow pattern and particle movement, which was recorded using the digital video camera, NanoSenze MKIII+, with a frequency up to 1000 frames per second. The temperature of the mixture was maintained at about $12{ }^{\circ} \mathrm{C}$ by the heat exchanger.

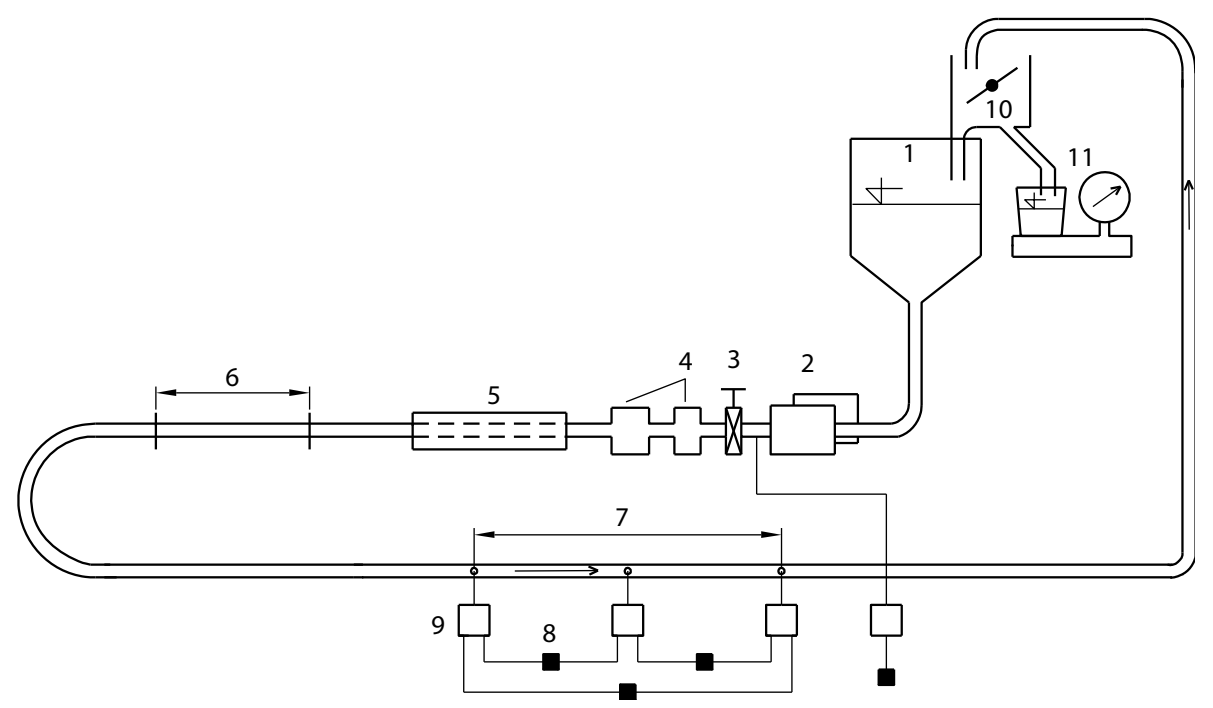

Fig. 1. Layout of the experimental pipeline loop (1 - slurry tank, 2 - pumps, 3 - control valve, 4 - flow meters, 5 - heat exchanger, 6 - transparent section, 7 - measurement section, 8 - pressure transducer, 9 - sedimentation vessels, 10 - flow divider, 11 - density and discharge measurement).
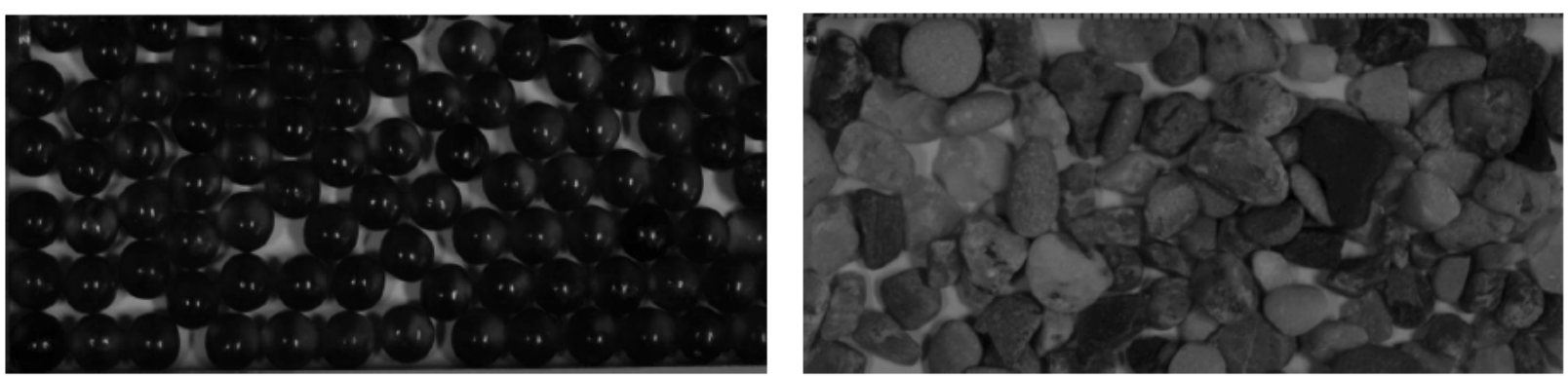

Fig. 2. Glass balls $\left(\rho_{p}=2540 \mathrm{~kg} \mathrm{~m}^{-3}, d=6 \mathrm{~mm}\right)$ and washed graded pebble gravel $\left(\rho_{p}=2650 \mathrm{~kg} \mathrm{~m}^{-3}, 4 \mathrm{~mm} \leq d \leq 8 \mathrm{~mm}\right)$.

The measured mixtures consist of bulk materials of different particle shape, but of the same mean diameter, $d_{50}=6 \mathrm{~mm}$. Glass balls $\left(\rho_{p}=2540 \mathrm{~kg} \mathrm{~m}^{-3}\right)$ and washed graded pebble gravel $\left(\rho_{p}=2650 \mathrm{~kg} \mathrm{~m}^{-3}\right)$ were used as model coarse-grained solids, see Fig. 2. The glass balls were of uniform size distribution (particle diameter $d=6 \mathrm{~mm}$ ), the graded pebble gravel has a narrow particle size distribution (particle diameter $d$ ranged from 4 to $8 \mathrm{~mm}$ ). Water was used as the carrier liquid. The volumetric concentration of the studied mixtures reached relatively low values ( $c_{v}$ ranged from 2.7 to $10.4 \%$ ). 
Because the density of the used solid materials slightly differs, the mixture density was used for comparison of the measured mixtures instead volumetric concentration, which is for gravel mixture and glass balls mixture with the same density slightly lower. The effects of the two different solid materials, flow velocity $V_{s}$, and volumetric concentration $c_{v}$ on the mixture flow behaviour, pressure drop versus the mean velocity relationship and flow pattern were studied experimentally.

\section{Pressure drop}

Flow of heterogeneous slurries may be defined by asymmetrical velocity and concentration distribution, where a Coulombic friction contributes to the friction losses. A flow pattern with a bed layer and a skew concentration distribution generally exist for these slurries (Wilson, 1976; Shook et al., 1986; Matousek, 2007; Sobota et al., 2009). The deposition velocity limit is at least of the same importance as friction losses for design and operation.

The effect of solids concentration and mean velocity on the mixture pressure drop $i_{s}$ versus the mean velocity $V_{s}$ relationship of glass balls and pebble gravel water mixtures is illustrated in Fig. 3 and 4.

The effect of particle concentration of spherical glass ball-water mixture is practically independent on flow velocity; on the contrary it slightly increases with decreasing velocity for gravel mixture.

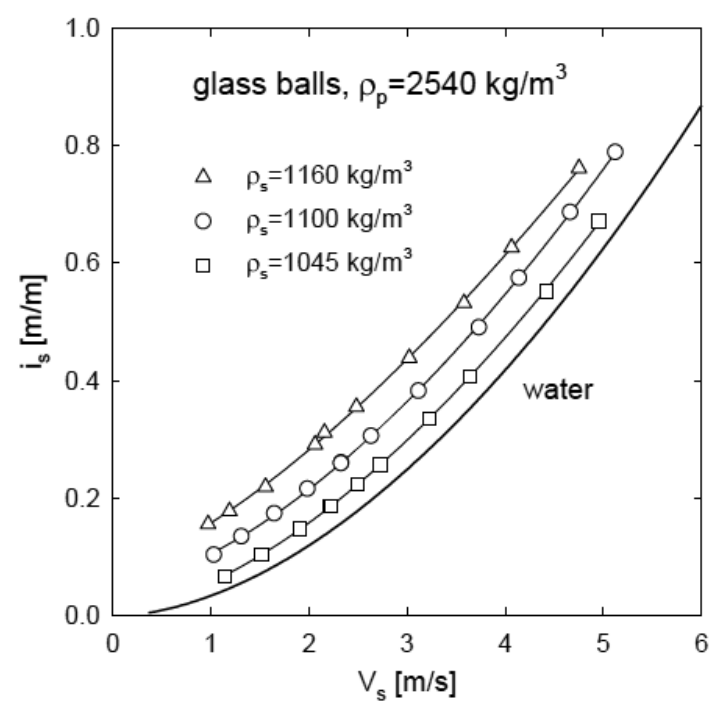

Fig. 3. Pressure drop $i_{s}$ versus mean mixture velocity $V_{s}$ for glass water mixtures ( $c_{v}=10.4,6.5$, and $2.9 \%$, respectively).
The effect of particle shape is negligible for lower mixture densities $\left(\rho_{s}=1045 \mathrm{~kg} \mathrm{~m}^{-3}\right.$ and $\rho_{s}=1100$ $\mathrm{kg} \mathrm{m}^{-3}$ ), the pressure drops are practically the same, see Fig. 5. For the highest measured slurry density $\rho_{s}=1160 \mathrm{~kg} \mathrm{~m}^{-3}$ a slight difference was found, it increases with decreasing mixture mean velocity. For low mixture velocity range the gravel particles, especially these of bigger size, slide along the pipe invert on the contrary of the glass balls, which move by rolling mode even at low velocities. The gravel sliding mode could be the reason for the slightly increasing pressure drop.

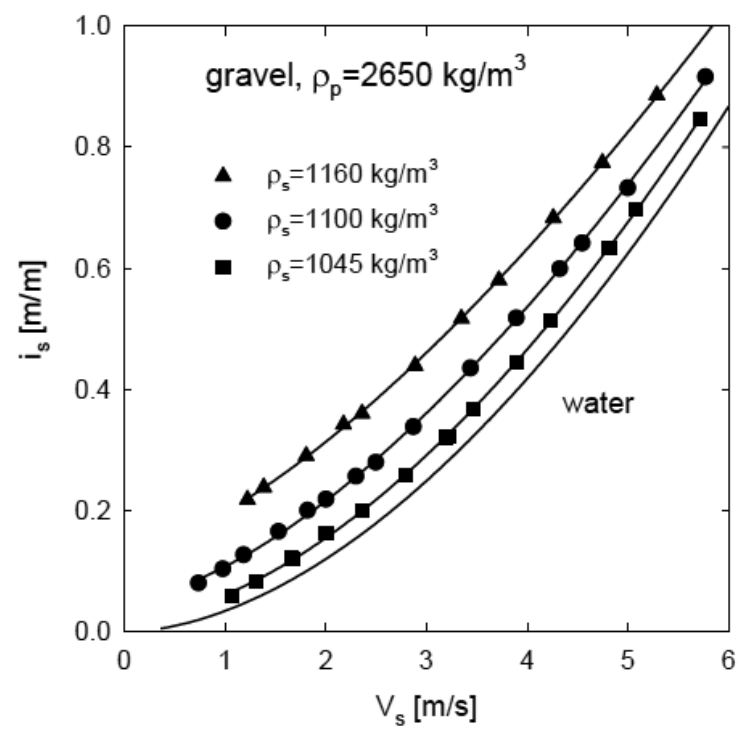

Fig. 4. Pressure drop $i_{s}$ versus mean mixture velocity $V_{s}$ for gravel water mixtures ( $c_{v}=9.7,6.1$, and $2.7 \%$, respectively).

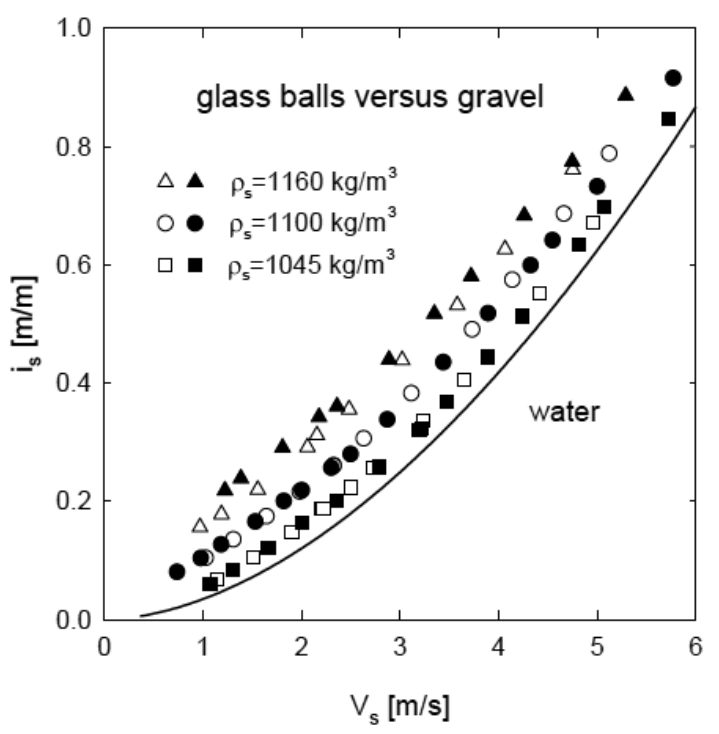

Fig. 5. Comparison of $i_{s} / V_{s}$ relationship for glass balls and gravel water mixtures. 
It was observed that both the studied mixtures were significantly stratified, however the two-layer model strongly underestimates the slurry pressure drop (Vlasak et al., 2011), see Fig. 6. It was visually confirmed that the studied mixtures do not create a real continuous bed layer.

Probably with regard to the particle size to pipe diameter ratio $d / D$ (which is about 0.17 ) they originate significant wall roughness of the pipe invert. The particles moving along the pipe invert give rise to large eddies, which substantially affect the mixture flow, mainly for higher flow velocities, and help the particles to reach the saltation or in some cases even freely suspended flow mode. The relative high value of slip velocity between carrier liquid and conveyed particles, mutual interaction and collisions of the particles, contribute to high level of turbulence not only in the lower section of the pipe. Additional pressure drop, which significantly increases the total pressure drop plays important role.

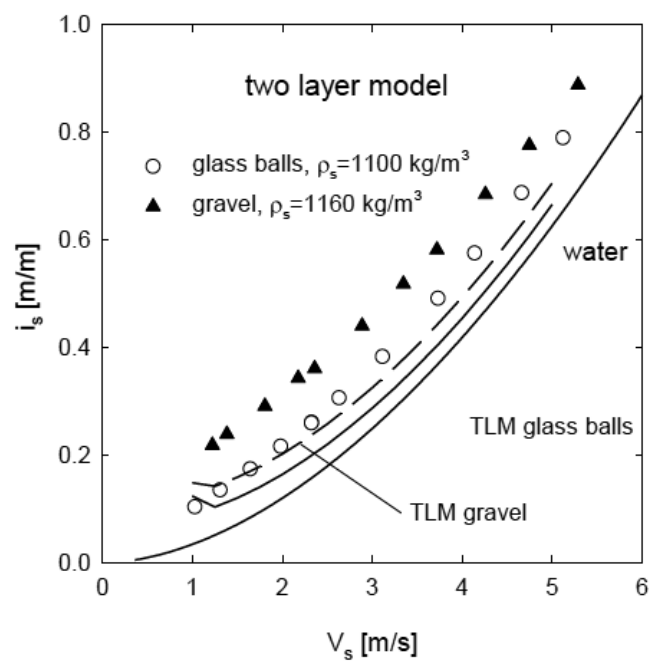

Fig. 6. Two layer model (TLM) approximation of glass ball $\left(c_{v}=6.5 \%\right)$ and gravel $\left(c_{v}=9.7 \%\right)$ water mixtures.

The Durand model well describes pressure drop even for the studied very coarse-grained particles (relative to the pipe diameter) for the mixture density $\rho_{s}>1100 \mathrm{~kg} \mathrm{~m}^{-3}$ (i.e. concentration $c_{v}>5 \%$ ). For lower mixture concentration (i.e. concentration $c_{v}<$ $5 \%$ ) it is valid for medium and higher flow velocities $\left(V_{s}>1.7 \mathrm{~m} \mathrm{~s}^{-1}\right)$, i.e. when $\mathrm{Fr}>8$, see Fig. 7 . However, this velocity range is better supported by the Durand model and the relationship $\varphi=91 \mathrm{Fr}^{-0.8}$ approximates well the flow behaviour of both glass ball and gravel water mixtures at medium and higher flow velocities.

\section{Particle and velocity distribution in a pipe}

The gravel and glass ball low concentrated mixtures $\left(\rho_{s}=1045 \mathrm{~kg} \mathrm{~m}^{-3}\right)$ flow were recorded using a digital video camera. The particles were significantly stratified, they moved mostly in a layer close to the pipe invert, however for moderate and higher flow velocities an intensive saltation, and even suspended flow of particles was observed. Some particles moved in the central and even upper regions of the pipe cross-section.
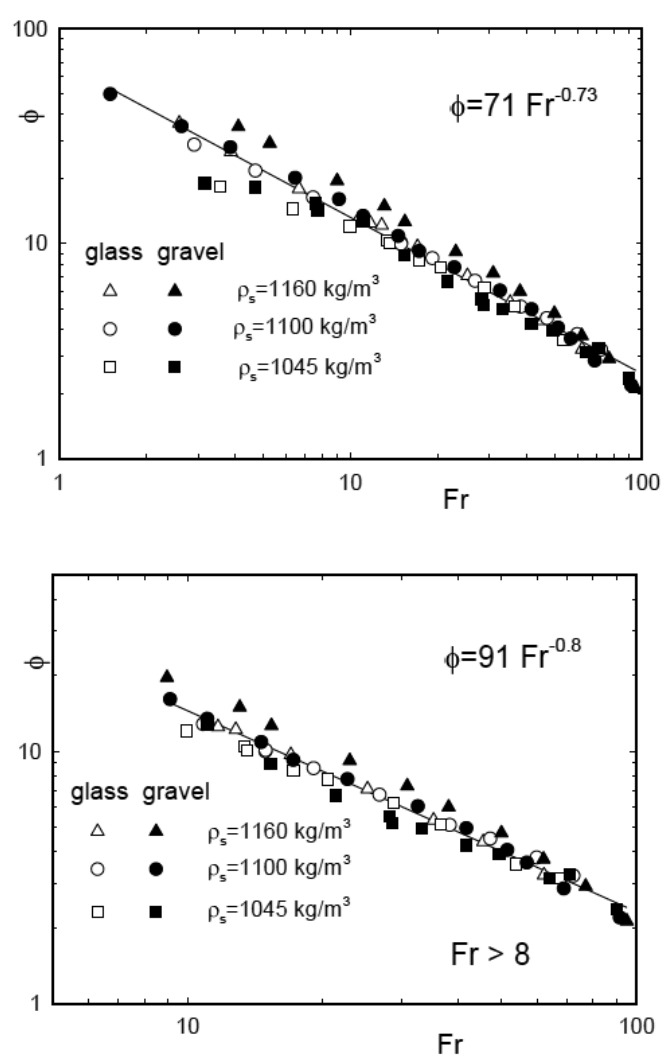

Fig. 7. Plot of Durand function $\varphi$ versus Froude number Fr.

The effect of the increasing slurry velocity on the glass ball water mixtures flow pattern and the particle vertical distribution is illustrated in Fig. 8. The glass balls mostly roll along the pipe invert for lower slurry velocities $\left(V_{s}=1.3\right.$ and $\left.1.5 \mathrm{~m} \mathrm{~s}^{-1}\right)$. However, they do not create a solid bed. The bed consists of only about one or two layers of particles. Some of the balls move in form of dunes along the pipe invert; some particles saltate with significant rotation in the lower part of the pipe. For higher mixture velocities $\left(V_{s}=1.8 \mathrm{~m} \mathrm{~s}^{-1}\right.$ and $\left.2.2 \mathrm{~m} \mathrm{~s}^{-1}\right)$ more and more particles move in the saltation mode, with some particles becoming fully suspended and can reach into the highest region of the pipe. 


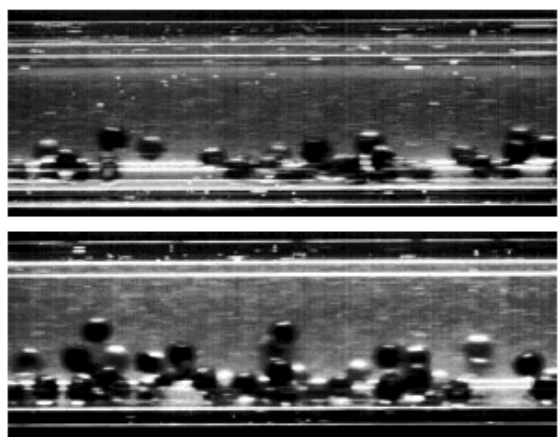

$$
V_{s}\left[\mathrm{~m} \mathrm{~s}^{-1}\right]
$$
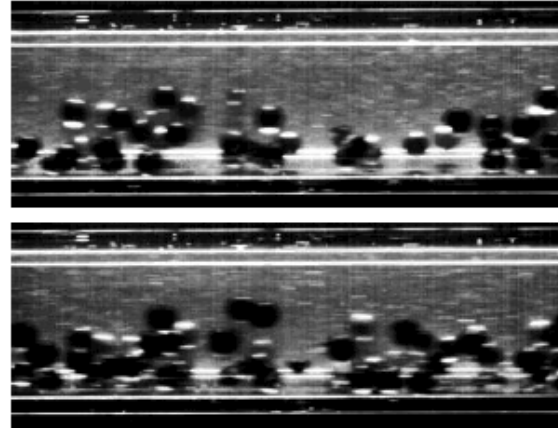

Fig. 8. Flow pattern of glass balls water mixture, $\rho_{s}=1045 \mathrm{~kg} \mathrm{~m}^{-3}\left(c_{v}=2.9 \%\right)$.
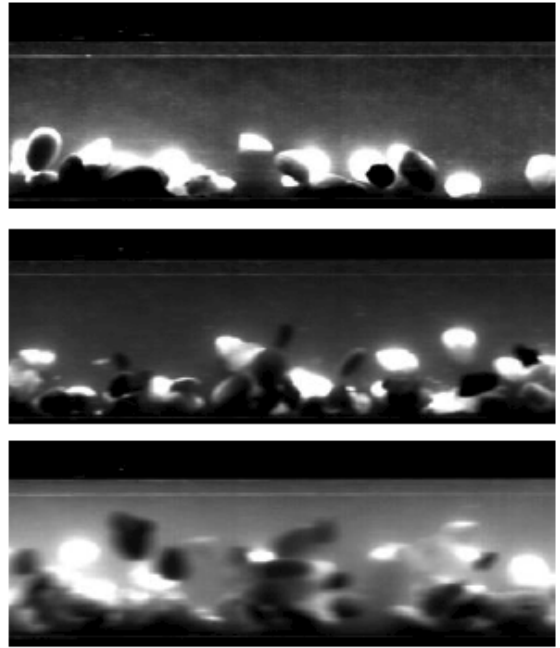

$$
V_{s}\left[\mathrm{~m} \mathrm{~s}^{-1}\right]
$$

1.0

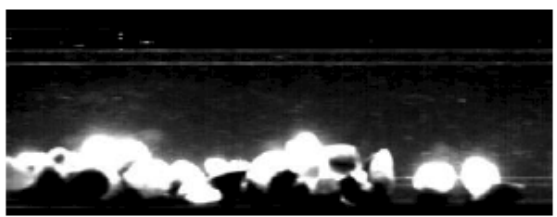

1.9

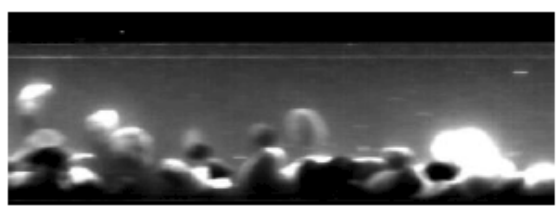

3.8

5.3

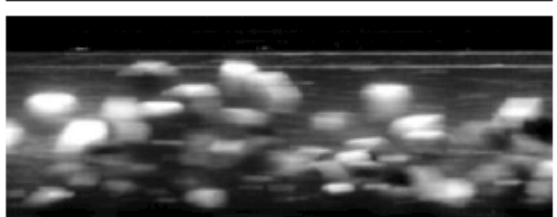

Fig. 9. Flow pattern of gravel water mixture, $\rho_{s}=1045 \mathrm{~kg} \mathrm{~m}^{-3}\left(c_{v}=2.7 \%\right)$.

The effect of the increasing mixture velocity on the mixture flow pattern and the particle distribution in vertical cross-section for low concentrated gravel slurry $\left(\rho_{s}=1045 \mathrm{~kg} \mathrm{~m}^{-3}\right)$ is well illustrated in Fig. 9. Depending on their shape, the gravel particles slide and roll along the pipe invert for the low mixture velocities $\left(V_{s}=1.0 \mathrm{~m} \mathrm{~s}^{-1}\right.$ and $\left.1.5 \mathrm{~m} \mathrm{~s}^{-1}\right)$. With the increasing mean mixture velocity the particle velocities also increase and individual particles pass to saltation mode $\left(V_{s}=1.9 \mathrm{~m} \mathrm{~s}^{-1}\right.$ and $\left.2.6 \mathrm{~m} \mathrm{~s}^{-1}\right)$. For the higher slurry velocities $\left(V_{s}=3.8 \mathrm{~m} \mathrm{~s}^{-1}\right)$ more and more particles lift off the pipe invert, move in the saltation mode and occupy the central part of the pipe, where local velocities reach maximal value. For the highest velocity range the saltation height and length (Lukerchenko et al., 2009a; 2009b) substantially increase. Some particles (especially the smaller ones) moves even suspended in the carrier liquid and can reach the top of the pipe $\left(V_{s}=5.3 \mathrm{~m} \mathrm{~s}^{-1}\right)$.

These results were confirmed also from time series of the particle motion, see Fig. 10. At low mixture mean velocities $\left(V_{s}=1.9 \mathrm{~m} \mathrm{~s}^{-1}\right)$ the gravel particles slide and roll along the pipe invert, the particles in the second layer or moving in saltation mode move faster in comparison with the particles in contact with pipe wall. With increasing mixture velocity more particles move in saltation mode. The particles moving in central part of the pipe reach significantly higher velocities than sliding or rolling particles moving in contact with pipe, as it is illustrated for mean velocity $V_{s}=2.6 \mathrm{~m} \mathrm{~s}^{-1}$. For flow velocities $V_{s}=3.8 \mathrm{~m} \mathrm{~s}^{-1}$ and more the saltation becomes very important mode of the particle movement. Substantial proportions of particles move in saltation mode with long length and height of the 
jumps or freely suspended in central area of the pipe cross-section.

The saltation of particles is essentially threedimensional process, what is possible to watch also from the visualisation of the pipe flow pattern. Particle-particle and particle-bed collisions represent the main mechanisms producing the lateral disper- sion of the saltating particles. This behaviour can be described only by the 3D pattern of particle motion (Lukerchenko et al., 2009a; 2009b). Similar particle motion can be observed in channel flows. In the pipe the particles move longitudinally and transversally and they can reach side wall of the pipe and slide along it.
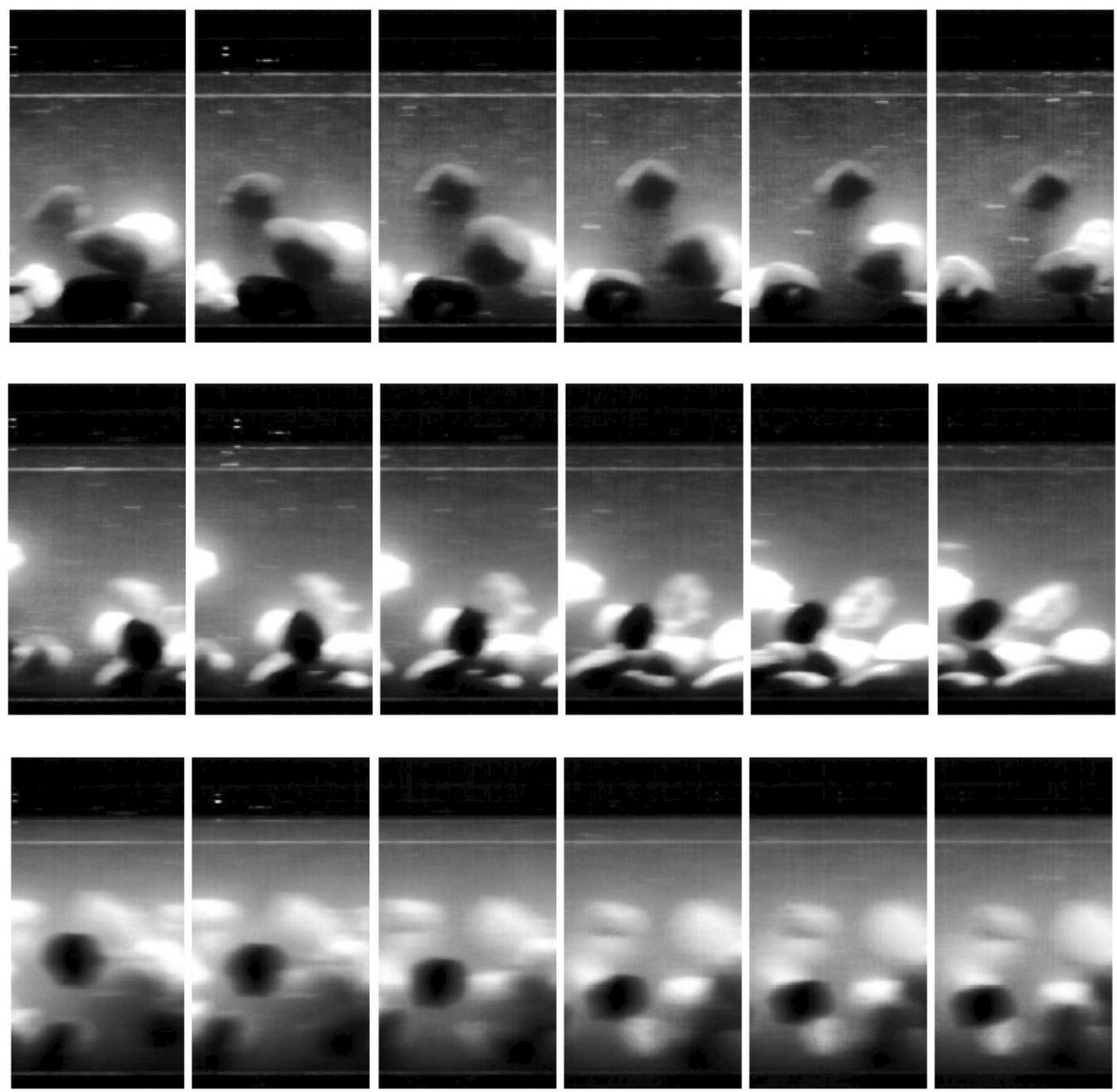

Fig. 10. Time series of gravel conveyed in water at different mean mixture velocity $V_{s}=1.9,2.6$, and $3.8 \mathrm{~m} \mathrm{~s}^{-1}$, respectively, $\rho_{s}=1045 \mathrm{~kg} \mathrm{~m}^{-3}\left(c_{v}=2.7 \%\right)$.

Visualisation of particle movement made possible to evaluate in some case local longitudinal velocity of individual particles $v_{p}$ and its dependence on the mean mixture velocity $V_{s}$ and distance $y$ of the particle centre of gravity from the pipe invert. The local particle velocity and the mean mixture velocity ratio $v_{p} / V_{s}$ and theoretical turbulent velocity profile (according to Blasius) are illustrated in Fig. 11. It can be seen that the slip velocity is prac- tically constant and independent on particle position in pipe.

We tried to determine also the water velocity distribution from movement of some tracer particles in upper part of the pipe, see Fig. 12. The local water velocity values were evaluated for two different flow pattern, so called without particles and with particles. The first one, without particles, illustrates the velocity distribution in the part of pipe, where 
conveyed particles are not instantaneously present. The second pattern represents distribution of water local velocity in pipe where particles are conveyed in the lower portion of the pipe cross-section. It this pattern the velocity profile is due heterogeneous distribution of particles asymmetrical, and local velocity values in the upper portion of pipe increases.

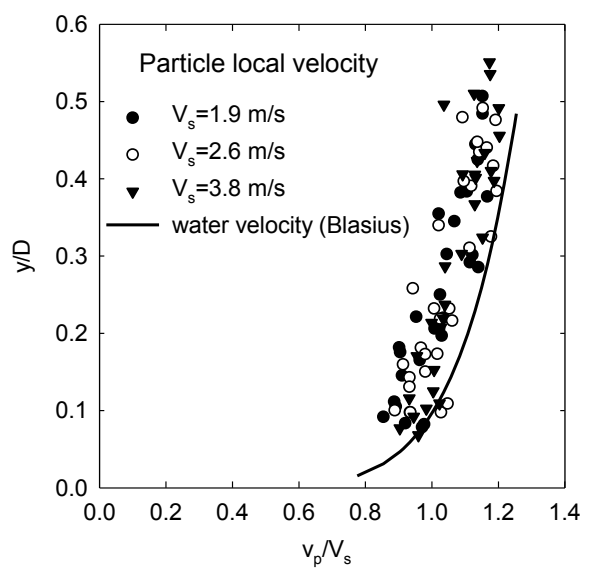

Fig. 11. Local particle velocity $v_{p}$ over mean mixture velocity $V_{s}$ ratio, gravel water mixture at different mean mixture velocity $V_{s}=1.9,2.6$ and $3.8 \mathrm{~m} \mathrm{~s}^{-1}$, respectively $\left(\rho_{s}=1045 \mathrm{~kg} \mathrm{~m}^{-3}\right.$, $c_{v}=2.7 \%$ ).

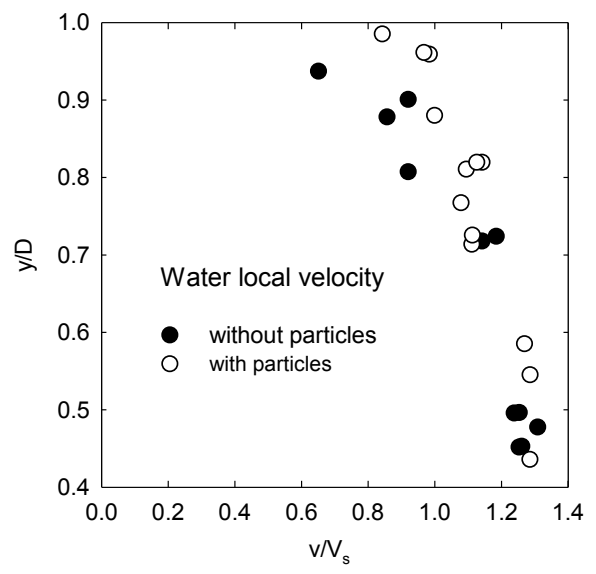

Fig. 12. Local water velocity $v$ over mean mixture velocity $V_{s}$ ratio, gravel water mixture at mean mixture velocity $V_{s}=$ $=1.9 \mathrm{~m} \mathrm{~s}^{-1}\left(\rho_{s}=1045 \mathrm{~kg} \mathrm{~m}^{-3}, c_{v}=2.7 \%\right)$.

\section{Conclusions}

The coarse-grained particle-water mixtures studied in the smooth pipe of relatively small diameter $(\mathrm{D}=36 \mathrm{~mm})$ were significantly stratified.

Asymmetrical velocity distribution was observed in the upper part of the pipe, i.e. the local velocity values increased in comparison with flow without bed formation. The difference between particle and water velocity values appears to be practically independent on particle distance from the pipe invert, and mean mixture velocity.

The study revealed that coarse-grained particles conveyed by liquid in pipe moved principally in a layer close to the pipe invert, however for moderate flow velocities $\left(1.6 \mathrm{~m} \mathrm{~s}^{-1}<V_{s}<1.8 \mathrm{~m} \mathrm{~s}^{-1}\right)$, saltation of particles was observed and particles were also present in the central and upper areas of the pipe cross section for flow velocities higher than $3.8 \mathrm{~ms}^{-1}$.

The narrow sized pebble gravel-water mixtures reached nearly the same hydraulic gradient as the glass ball-water mixtures of the same particle mean diameter, the difference increased with increasing concentration.

The Durand model accurately predicted the flow behaviour of coarse-grained particle-water mixtures for moderate and higher flow velocities and Durand number (for $V_{s}>1.7 \mathrm{~m} \mathrm{~s}^{-1}$, i.e. Fr $>8$ ). The accuracy of this model is influenced by the model parameters, which should be determined experimentally. The Durand model can be recommended for scale up of the frictional pressure drops at moderate and higher flow velocities $\left(V_{s}>1.7 \mathrm{~m} \mathrm{~s}^{-1}\right)$.

The two-layer model significantly underestimates the mixture pressure drop. This is probably due to an extremely high value of pipe/particle diameter ratio, resulting in amplified particle/particle and particle/pipe wall interactions, which significantly contribute to higher energy consumption and particle saltation movement.

Acknowledgement. The support under the project P105/10/1574 of the Grant Agency of the Czech Republic and the Institutional Research Plan No. AV0Z20600510 of Academy of Sciences of the Czech Republic is gratefully acknowledged.

\section{List of symbols}

$A_{i} \quad-\quad$ cross-sectional area of upper and lower layers $\left[\mathrm{m}^{2}\right]$,

$c_{v}, c_{i}-$ volume concentration of particles [-],

$d-$ particle diameter $[\mathrm{m}]$,

$d_{50} \quad-$ mean particle diameter $[\mathrm{m}]$,

$D \quad-\quad$ inner diameter of pipe [m],

$f_{12}-$ interfacial friction factor $[-]$,

$F_{2}-$ Coulombic force [ $\mathrm{kg} \mathrm{m} \mathrm{s}^{-2}$ ],

$\mathrm{Fr} \quad-$ slurry Froude number [-],

$\mathrm{Fr}_{w} \quad-$ mean particle Froude number $[-]$,

$i \quad-$ hydraulic gradient $\left[\mathrm{m} \mathrm{m}^{-1}\right]$,

$K$ - material constant [-],

$S_{i} \quad-$ perimeter of upper and lower layers [m],

$v \quad-$ local longitudinal velocity of carrier liquid $\left[\mathrm{m} \mathrm{s}^{-1}\right]$,

$v_{p} \quad-$ local longitudinal velocity of individual particles [ $\mathrm{m} \mathrm{s}^{-1}$, 
$V \quad-$ mean velocity $\left[\mathrm{m} \mathrm{s}^{-1}\right]$,

$w_{50}$ - the settling velocity of a $d_{50}$ sized particle $\left[\mathrm{m} \mathrm{s}^{-1}\right]$,

$y \quad-\quad$ vertical distance from pipe invert [m],

$\alpha, \beta-$ slurry material parameters [-],

$\rho \quad-$ density $\left[\mathrm{kg} \mathrm{m}^{-3}\right]$,

$\tau \quad-$ shear stress $\left[\mathrm{kg} \mathrm{m}^{-1} \mathrm{~s}^{-2}\right]$,

$\varphi \quad-$ Durand function [-]

Subscripts

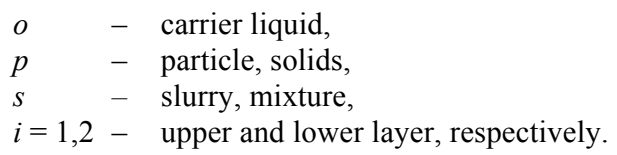

\section{REFERENCES}

DURAND R., 1951: Transport hydraulique de graviers et galets en conduite. La Houille Blanche, No. Special B (1951), 609-619.

DURAND R., CONDOLIOS E., 1952: Hydraulic transport of Coal. in Proceedings of National Coal Board. Pap. IV, 39-55 , London, U.K.

GILLIES R. G., SHOOK C. A., 2000: Modeling high concentration settling slurry flows. Can. J. Chem. Engng, Vol. 78, 709-716.

GILLIES R. G., SHOOK C. A., WILSON K. C., 1991: An improved two layer model for slurry flow. Can. J. Chem. Engng, Vol. 69, 173-178.

GOVIER G.W., AZIZ K., 1972: The flow of complex mixtures in pipes. Van Nostrand Rein. Comp., N. York.

KUPKA F., HRBEK J., JANALIK J., 1970: Hydraulic transport in pipelines. (In Czech.) SNTL, Praha.

LUKERCHENKO N., PIATSEVICH S., CHARA Z., VLASAK P., 2009a): 3D numerical model of a spherical particle saltation in channel with rough fixed bed. J. Hydrol. Hydromech., Vol. 57, No. 2, 100-112.

LUKERCHENKO N., PIATSEVICH S., CHARA Z., VLASAK P., 2009b): Numerical model of the spherical particle saltation in channel with transverse tilted rough bed. J. Hydrol. Hydromech., Vol. 57, No. 3, 182-190.

MACIEJEWSKI W., OXENFORD J., SHOOK C., 1993: Transport of coarse rock with sand and clay slurries, Proc. of HYDROTRANSPORT 12, Brugge (Belgium), BHR Group Conference Series No. 6, BHR Group Limited, Cranfield (U.K.), 705-724.

MATOUSEK V., 1997: Flow mechanism of sand-water mixtures in pipelines. [PhD Thesis.], Delft University of Technology, Delft University Press, Delft (The Netherlands).

MATOUSEK V., 2005: Research developments in pipeline transport of settling slurries. Powder Technology, Vol. 156, No. $1,43-51$.

MATOUSEK V., 2007: Distribution of medium-sand particles in flow above erodible bed. J. Hydrol. Hydromech., Vol. 55, No. 4, 274-281.

MATOUSEK V., 2009: Concentration profiles and solids transport above stationary deposit in enclosed conduit. JHE ASCE, 135, 12, 1101-1106.

MATOUSEK V., KRUPICKA J., 2009: On equivalent roughness of mobile bed at high shear stress. J. Hydrol. Hydromech., Vol. 57, No. 3, 191-199.
NEWITT D. M., RICHARDSON J. F., ABBOTT M., TURTLE R. B., 1955: Hydraulic conveying of solids in horizontal pipes. Transaction Institute of Chemical Engineers, 33, 2, 93-113.

PULLUM L., GRAHAM L. J. W., SLATTER P., 2004: A nonNewtonian two-layer model and its application to high density hydrotransport. Proc. of HYDROTRANSPORT 16, Santiago (Chile), BHR Group (U.K.), 579-593.

SHOOK C. A., GELLER L., GILLIES R. G., HUSBAND W. H. W., SMALL M., 1986: Experiments with coarse particles in a $250 \mathrm{~mm}$ pipeline. Proc. of HYDROTRANSPORT 10, Innsbruck (Austria), BHRA Fluid Engineering Centre, Cranfield (U.K.), Paper F4, 219-227.

SHOOK C. A., ROCO M. C., 1991: Slurry Flow: Principles and Practice. Butterworth/Heinemann.

SHOOK C. A., GILLIES R. G., SANDERS R. S., 2002: Pipeline hydrotransport with application in the oil sand industry. SRC Publication No. 11508-1E02, Canada.

SILIN N. A., KOBERNIK S. G., 1962: Rezimy raboty krupnych zemlesosnych snarjadov i truboprovodov. (In Russian.) (Modes of large dredging installations and hydraulic pipelines operation). AN USSR Publisher, Kiev.

SOBOTA J., VLASAK P., STROZIK G., PLEWA F., 2009: Vertical distribution of concentration in horizontal pipeline - density and particle size influence. Proc. of the Eighth (8) ISOPE Ocean Mining (\& Gas Hydrates) Symposium, Chennai (India), 220-224.

STREAT M., BANTIN R. A., 1972: Mechanism of hydraulic conveying at high concentrations in vertical and horizontal pipes. Proc. HYDROTRANSPORT 2, Coventry (England), BHRA Fluid Engineering (U.K.), Paper B2, 11-24.

VLASAK P., CHARA Z., 2004: Laminar and turbulent transition of fine-grained slurries. Particulate Science and Technology, Vol. 22, No. 2, 189-200.

VLASAK P., CHARA Z., 2007: Effect of particle size and concentration on flow behavior of complex slurries. Proc. of The 7th ISOPE Ocean Mining Symposium, Lisbon (Portugal), 188-196.

VLASAK P., CHARA Z., 2011: Effect of particle size distribution and concentration on flow behavior of dense slurries. Particulate Science and Technology, Vol. 29, No. 1, 53-65.

VLASAK P., CHARA Z., STERN P., 2010: Drag reduction of dense fine-grained slurries, J. Hydrol. Hydromech., Vol. 58, No. 4, 261-270.

VLASAK P., CHARA Z., KYSELA B., SOBOTA J., 2011: Flow behavior of coarse-grained slurries in pipes, in Proceedings of the Nineth (2011) ISOPE (Deep) Ocean Mining (\& Gas Hydrates) Symposium, 19-25 June 2011, Maui (Hawaii, USA), 158-164.

WILSON K. C., 1976: A unified physically based analysis of solid-liquid pipeline flow. Proc. of Hydrotransport 4, Banff, Alberta (Canada), BHRA (U.K.), Paper A1, 1-16.

WILSON K. C., THOMAS A. D., 1985: A new analysis of the turbulent flow of non-Newtonian fluids. Canad. J. Chem. Engng., Vol. 63, 539-546.

ZANDI I., GOVATOS G., 1967: Heterogeneous flow of solids in pipelines. Proc. ASCE, 93, HY7, 145-149.

Received 10 October 2011 Accepted 13 March 2012 